\title{
Mobile Communication Device Usage: Perceptions of Non-Supervisory Employees
}

Beverly Muhammad, Northcentral University, USA Conja Wright, University of Phoenix, USA

Pamela J. Van Den Bussche, University of Phoenix, USA Jaime Klein, Northcentral University, USA

\begin{abstract}
The increased usage of mobile communication devices (MCDs) in the workplace has been controversial regarding whether they increase or decrease productivity, whether work-life balance is affected by use, and whether employers have the right to monitor usage. This paper includes research that addressed each of these three issues linked to employee use of MCDs. Past research provided conflicting results in three areas - work-life balance, productivity, and employee monitoring.

A quantitative study of 60 non-supervisory employees in Arizona, Michigan, and Illinois, consisting of an online survey, was carried out to determine perceptions of whether use of MCDs for work purposes affects work-life balance or productivity and perceptions on employers monitoring usage of work-issued MCDs.

Sixty-seven percent of respondents stated that their duties require the use of MCDs and, of those $62 \%$, each stated that his or her MCD is a Smartphone. The majority stated that Smartphones were MCDs given to them by the employer. Other MCDs were cell phones and tablets which, combined, accounted for $35 \%$ of the responses. Fifty-three percent of the respondents stated that the use of the MCD did not impact work-life balance, eighty-eight percent stated that the use of the MCD increased productivity, and eighty-seven percent stated that their employer does not monitor usage of their MCD.
\end{abstract}

Research findings may vary and depend on participants. Supervisors may have different viewpoints. However, the required use of these devices in the workplace keeps increasing, so it is appropriate for employers to clearly find a benefit for their use.

Keywords: Smartphones; Mobile Communication Devices; Work Life Imbalance; Employer Monitoring

\section{INTRODUCTION}

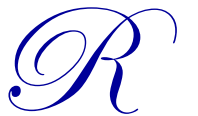

esearchers have captured the importance of cell phones in the lives of people and found that cell phones have changed the way they live and created the perception that they cannot live without them (PEW, 2006). In fact, the technology of mobile communication device(s) has rapidly advanced from cell phones to Smartphones with features that further increase the perception of necessity and greater usage. Moreover, $82 \%$ of American adults own mobile communication device(s) (Smith, 2010). With this increased usage and functionality, recent research (Petrecca, 2010; Moore \& Pack, 2011; Cousins \& Varshney, 2009; Kalkbrenner \& Mccampbell, 2011) unveiled three common topics of societal concern: 1) conflict in the boundaries between work and personal life, 2) concerns with productivity, and 3) rights of employers to monitor mobile communication devices used by their employees.

Blurring of the boundaries between work and personal life is perceived by mobile communication device users based on their different philosophies on work-life balance (Moore \& Pack, 2011; Cousins \& Varshney, 2009). 
PEW (2006) gave emphasis to a growing gap between how younger (18-29 years old) and older cell phone users (over 30 years old) use their mobile communication device(s) and view the importance of them in their lives (PEW, 2006). This dissimilarity of philosophies may create discord between individuals within these two groups.

How employees view the mega trend of mobile communication device(s) should be studied further because it will affect how managers, lawyers, human resource professionals, and social scientists craft policies and procedures in the workplace in the next several years. In truth, there is current discourse regarding issues of mobile communication devices intertwined with work-life balance and productivity (Ahmad \& Orton, 2010; Mooney \& Lyne, 2010). One argument is that the lost productivity concerns include distractions, Internet use, and personal emails and phone calls (Petrecca, 2010). Exploring this trend now, to discover the gaps in perceptions and begin a discourse with today's workers who are assisting organizations in crafting policies and procedures that will sustain their future needs, is paramount. The discourse concerning whether mobile communication technology is increasing or decreasing productivity has as much media time as the issue of the rights of employers to monitor their employees.

These conflicts are increasing, particularly regarding the right for employers to monitor company assets versus the employees' right to privacy as they use company resources. The privacy concerns include employers' right to monitor employees' calls, track employees through use of a Global Positioning System (GPS) via Smartphone and other technology devices, and the rights of employers' use of cameras to protect companies' trade secrets and prevent hostile work environment situations (Petrecca, 2010; Shilton, 2009; Wicker, 2011).

Glimpses into the importance of mobile communication devices begins with a review of recent dialogue and common themes, descriptions of the research methodologies used to capture data, a discussion and conclusion related to the trends identified, limitations of the research studies, and suggestions for future research. These are linked to the proliferation of mobile communication device(s) usage.

This research study captures the experiences of non-supervisory employees, their use of these mobile communication devices, and research that suggests the need to answer three questions of concern regarding mobile communication devices:

1. Do workers believe mobile communication devices create work-life imbalance?

2. $\quad$ Do workers believe mobile communication devices diminish productivity?

3. Do workers believe employers have a right to monitor mobile communication device usage?

Throughout this paper, the phrase "mobile communication devices" will be referred to as MCDs and the non-supervisory employees will be referred to as participants. There are varying concepts related to the three areas of concern (work-life imbalance, productivity, and right to monitor) that this research is intended to address given the recent dialogue and research.

\section{Recent Dialogue}

Research relating to the ever-evolving advancements of MCDs' (Smartphones, cell phones, laptops, tablets, eReaders, etc.) features and their influence on employees is slowly increasing. While several MCD producers consistently discuss the advantages of MCDs for profitability, some researchers are discussing the influence that these devices have on society and productivity in the workplace (Petrecca, 2010; PEW, 2006). Since their proliferation, work-life balance, productivity, and employers' right to monitor them are significant concerns.

\section{Work-Life Balance}

The growth of MCD usage is commonplace, along with the growing societal expectation that everyone has one or more as a means of communication - hence, individuals may be contacted anywhere at any time. Likewise, MCDs have distorted the demarcation between home and work, particularly because these devices are accessible everywhere and at any given time. This has both positive and negative connotations. While some individuals feel MCDs do not infringe on their private time (Moore \& Pack, 2011), others have reported that MCDs negatively 
affect their personal lives because they find themselves working when they should be spending quality time with their families (Cousins \& Varshney, 2009). Similarly, the Society of Human Resource Management (Gurchiek, 2010) reported $89 \%$ of U.S. residents indicated work-life balance as a problem, and half of them reported the problem being significant (Ceniceros, 2011). Work-life balance, in general, has posed challenges for societies worldwide with the increase of MCDs (Lee, 2011; Cousins \&Varshney, 2009; Ceniceros, 2011; Goodman, 2011; Chesley, 2010).

Some individuals emphasized that although employers are not explicitly suggesting employees work long hours, the workload often requires it (Ceniceros, 2011). Employers provide MCDs to their employees as a means of increasing productivity (Ceniceros) but surreptitiously expect responsiveness to clients or customers at any given time. Research is warranted to determine how employees feel about the impact that MCDs have on their work-life balance as well as their work productivity.

\section{Mobile Communication Devices and Productivity}

Discussions are taking place as to how MCDs affect productivity. Some researchers suggest that various MCDs increase productivity (D'Souza, 2010), while others say they have not increased productivity. Kalkbrenner and Mccampbell (2011) conducted an online survey of over 80 individuals from various companies in the private and government sectors concerning their Smartphones and standard cell phones to determine perceptions concerning productivity. Sixty-two percent responded that productivity increased and eighteen percent reported productivity greatly increased. Twelve and a half percent reported productivity was unaffected and 6.2 percent reported a decrease in productivity. The findings of Kalkbrenner and Mccampbell's (2011) study overwhelmingly suggest that Smartphones or their derivatives increased their productivity more so than cell phones.

Other researchers have documented specific job functions that may benefit with increased productivity when using Smartphones (Mooney \& Lyne, 2010; Greene, 2012; Nelson, 2012). The Vice President of research for Nucleus Research suggested that sales professionals' productivity increased by 14.6 percent because of Microsoft mobile CRM applications (Greene, 2012). Nelson suggested that mobile applications are increasing engineers' ability to access data and the applications facilitate the engineers' designs and test functions, thus increasing productivity. Although mobile applications are not MCDs, they are enablers and are more or less married to various MCDs.

With all that has been said about the advantages that employees and employers experience from the use of MCDs and how significant these devices have become to employees' daily functioning, it is necessary to consider the views of opposing researchers who claim that there is a marked decrease in productivity and quality of the tasks or work of the users who multitask or quickly switch tasks when using MCDs. The very act of texting, answering the phone or electronic messaging and transmitting messages, all while attempting to perform one's assigned duties, is cited as an act that slows down the work of a healthy brain (Rubenstein, Meyer \& Evans, 2001).

Additionally, from one employer's perspective, MCDs were not necessarily linked to productivity. IBM conducted a study to test the hypothesis that there was a direct correlation between Smartphones and productivity. Their findings were surprising. Unlike they expected, the employees were using their Smartphones to access support and get quick updates instead of processing large amounts of instructional information as expected. IBM reconstructed their smartphone application to help promote their expected results (Ahmad \& Orton, 2010).

From the employees' perspective, Peter Mooney (2010) conducted a study and confirmed that although employees felt their Blackberries promoted quick email responses, most of the employees felt they could not effectively respond until they were back at their desks. Also, Mooney's study confirmed that workers spend approximately 90 minutes per work day surfing the Internet.

The studies suggest that some employees align with the employers' hypothesis that MCDs increase productivity while others oppose. Those who oppose believe that MCDs do not necessarily increase their productivity. This dichotomy suggests that MCDs and whether they promote productivity is still being debated and that further research is needed. 
Another predominate MCD topic that researchers are discussing is employers' right to monitor usage. Some individuals refer to monitoring of societal activities as the "Big Brother" system. Debates concerning employers' right to monitor are becoming prevalent.

\section{Employers' Right to Monitor}

Researchers have characterized the workplace and the issue of employee privacy as a virtual fishbowl, cautioning employees that it is in their best interests not to rely on misplaced expectations of privacy (Deloitte, 2009). With the many forms of monitoring technology accessible to employers due to widespread innovation and the lowered cost of surveillance equipment, ever-present monitoring of the workplace has resulted as an inevitable evolutionary process.

The focus here is one category of technology - that of MCDs. A multiplicity of methods exist which employers have utilized to monitor employees, including video surveillance, e-mail and voice mail monitoring, location tracking, Internet website monitoring, and computer keystroke tracking. Today, employers justify the necessity of these monitoring methods; these justifications include:

1. Ownership of the systems (phones and computers) used by employees

2. Responsibility for employee productivity and quality control

3. Guarantee of a safe workplace

4. Protection of intellectual property

Connecticut state labor law requires employers to inform employees prior to implementing electronic monitoring (Ciocchetti, 2010). So, the question is, "Should all states require employers to inform their employees of electronic monitoring activities prior to and during their employment?" The importance of this question cannot be understated, especially since the high court ruling in Ontario v. Quon (2009) provided employers with a legal defense when dealing with monitoring employee communications when those employers apprised employees prior to monitoring. The courts have stated, by the very act of accepting or continuing to work in the face of this knowledge of monitoring, that the employee is considered to be in contractual agreement with the employer's right to monitor. This act of prior notification will absolve employers who seemingly breach an employee's privacy. Employers must be careful to avoid surreptitious monitoring because of the risks (Supreme Court, 2009).

The Supreme Court ruled against Quon and established a new legal standard for similar types of privacy cases - when government employees are issued interactive communication devices and they are told ahead of time that they will be monitored, the government agency can look into employees' communication logs without violating their constitutional rights. Quon is one of the first cases to address whether the same rule applies when the employee's communication is transmitted through a third-party service provider under contract with the employer. The issue has gained increasing importance as a large number of employees use text messaging through third parties during the workday.

Conversely, under federal case law, an important exception is made for personal calls. When an employer realizes a call is personal, he or she must immediately stop monitoring the call. However, when employees are told not to make personal calls from specified business phones, the employee then takes the risk that calls on those phones may be monitored.

One of the concerns that is surfacing is how aware or unaware employees are of the extent to which their employers are monitoring their communications. What is the perception of these employees in reference to the existing potential for their employer to breach employee privacy? Today, there are very few laws regulating employee monitoring. There are many mobile device users who have yet to realize that a cell phone, smartphone or wireless laptop systematically broadcasts its location once power is turned on, whether a call is in progress or not. Employee lack of awareness could create a legal issue for employers. Employers who decide to monitor employee activities on company-owned computers, Smartphones and other devices should have a clear written policy explaining to employees that they should have no expectation of privacy in their use of these devices and that the employer may monitor their activities, including e-mail content and internet usage, randomly (Moore \& Pack, 2011). 
The future depends upon continued publicized cases of employer privacy abuse, which may result in swaying public opinion and pressuring jurists to revisit their prior opinions. As employees become exposed to the litigious nature of employer rights to monitoring, they will develop keener insights with regard to their employer's surveillance policy. Despite the current absence of standardized state and federal laws regulating employers' monitoring practices, there is good reason to believe that employers and employees will require legal clarification and clear delineation of rights to protect the concerns of both entities.

The sections that follow include the description of the research methodology used to uncover answers to MCDs related to work-life imbalance, productivity, and monitoring. The research findings, discussion and conclusion, limitations of the research study, and directions for future research are intended to add clarity to the recent dialogue concerning these topics. The combination of these sections is also intended to add to the body of knowledge.

\section{RESEARCH METHODOLOGY}

Through the distribution of an online survey, 60 employed non-supervisory adult participants of this research study confirmed their routine use of MCDs. The participants were primarily from the Illinois, Michigan, and Arizona with small numbers of participants from other states. Participants were asked to self-report their job titles and industries to confirm the variety of industries and positions incorporated into the study. The minimum age of the participants was 18 years old with no upward age limitation. No stipulations were made as to the participants' gender, ethnicity, or cultural background. Data collection extended over a period of 14 days.

The online responses are categorized by question and statement type. Some of the findings of this research study augment the work of various researchers. The comprehensive list of the research survey findings (Figures 115) are within Appendix A. The next section contains research charts depicting the most relevant findings given the topics of concern.

\section{RESEARCH SURVEY FINDINGS}

Sixty non-supervisory employees provided their perceptions on the importance of MCDs. This was a $40 \%$ rate of response. The survey contained a combination of questions and statements linked to their professions. Sixtyseven percent (Figure 1) of the participants reported employment duties that require use of their MCDs to conduct business, and sixty two percent (Figure 2) of the participants identified their Smartphones as the mobile device used for business purposes.

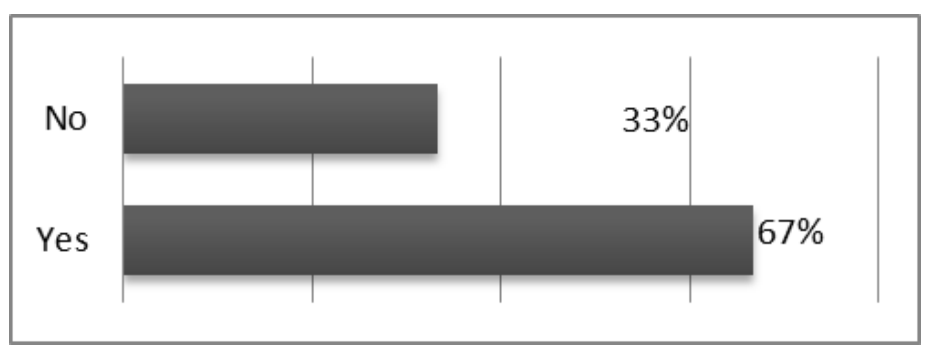

Figure 1: - Do Your Employment Duties Require The Use Of Mobile Communication Devices To Conduct Business? 


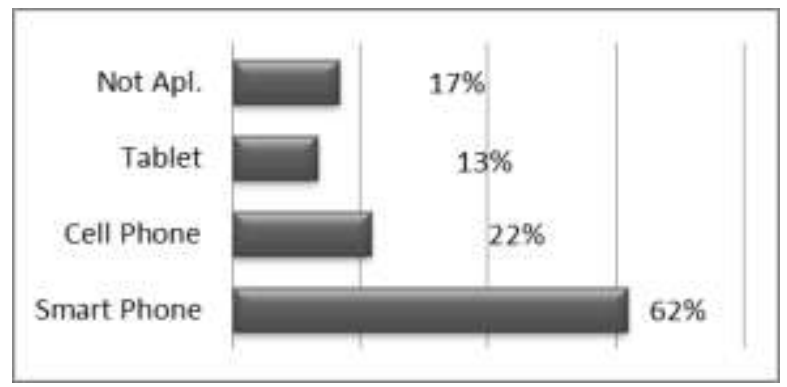

Figure 2: Select The Mobile Communication Devices You Use For Business.

The remaining questions and statements were categorized to answer the initial research questions: 1) Do workers believe mobile communication devices create work-life imbalance?, 2) Do workers believe mobile communication devices diminish productivity?, and 3) Do workers believe employers have a right to monitor mobile communication device usage?

\section{Work life Balance Survey Findings}

Figure 3 depicts the participant's responses to the statement "Mobile communication devices have created an imbalance between work and personal life." Although most of the participants say that MCDs do not create an imbalance, notice there is a small variance in those who disagree and those who agree.

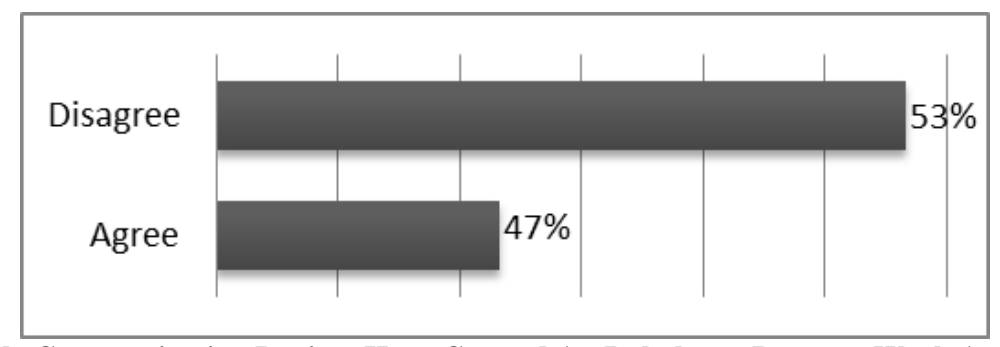

Figure 3: Mobile Communication Devices Have Created An Imbalance Between Work And Personal Life.

\section{Productivity Survey Findings}

Figure 4 reflects the participants' responses to the question "How many times per day does your mobile communication device interrupt your productivity during work hours?" The category titled "N/A" is not clear and may imply a number of things. However, this question was intended to uncover whether participants were experiencing interruptions via MCDs during work hours. It seems that the interruptions may be minimal.

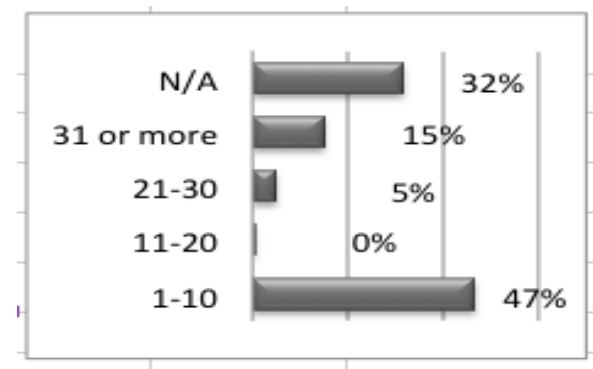

Figure 4: How Many Times Per Day Does Your Mobile Communication Device Interrupt Your Productivity During Work Hours?

Figure 5 reflects the participants' responses to the statement "Select the company-owned Mobile Communication Device(s)", indicating that the majority of employees used employer-owned MCDs; specifically, Smartphones were the majority. 


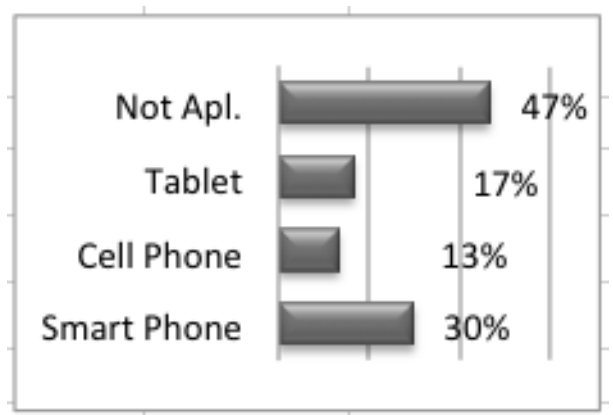

Figure 5: Select The Company Owned Mobile Communication Device(S).

Figure 6 reflects the participants' responses to "Does your employer have a policy requiring you to turn off your cell phone?" The majority answered "no". The purpose of this question was to discover if employees were aware of policies regarding cell phone use during work hours.

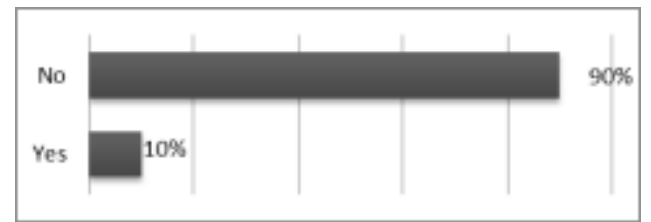

Figure 6: Does Your Employer Have A Policy Requiring You To Turn Off Your Cell Phone?

Figure 7 reflects that the majority of participants' disagreed with the statement "Mobile Communication Devices are a distraction." However, there was a small variance between those who disagreed and those who agreed. This unexplained variance, coupled with the responses to Figure 4 that asks "How many times per day does your mobile communication device interrupt your productivity during work hours?", appears ambiguous. This ambiguity requires additional research.

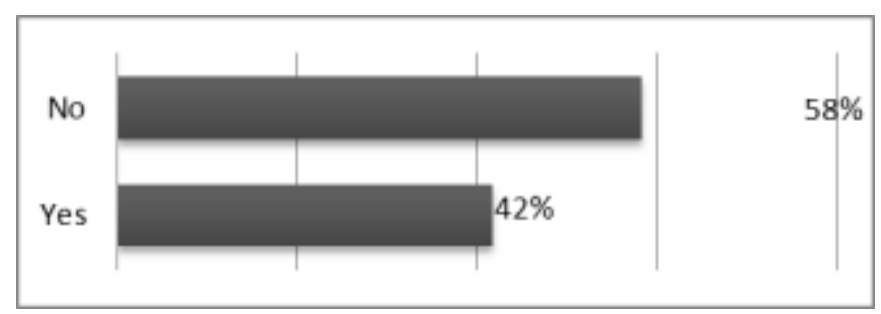

Figure 7: Mobile Communication Devices Are A Distraction.

Figure 8 reflects the participants' responses to the statement "Using Mobile Communication Devices has increased my productivity." The majority of participants agreed to this statement. So, although most participants experience few interruptions during the day, some reported that MCDs are a distraction while others reported that they are not, yet the majority reported that MCDs increase their productivity.

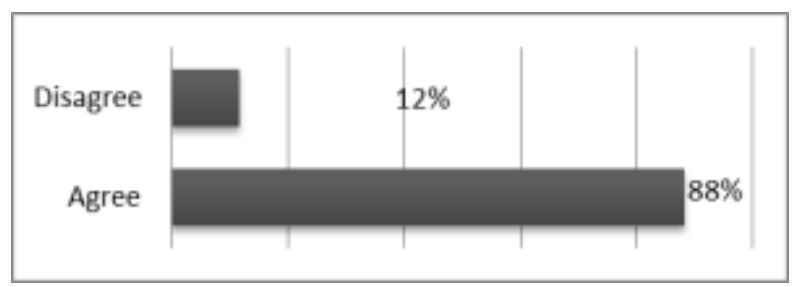

Figure 8: Using Mobile Communication Devices Has Increased My Productivity. 


\section{Workplace Monitoring Survey Findings}

Figure 9 reflects the participants' responses to the statement "Does your employer monitor your Mobile Communication Device(s)?" The majority stated "no" that their employers do not monitor. This may imply one of three things: 1) that the employer is not monitoring, 2) that the employer is monitoring and not informing, or 3) that the employer is monitoring and has informed the employee but the employee remains unaware.

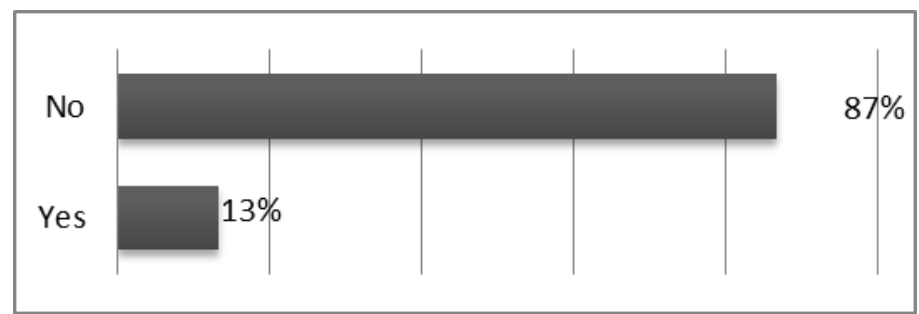

Figure 9: Does Your Employer Monitor Your Mobile Communication Devices?

Figure 10 reflects the participants' responses to the statement "My employer has the right to monitor employee mobile communication device usage." There is a very small variance in the responses to this statement. Some participants (43\%) believe that their employers have the right to monitor, while others (57\%) disagree.

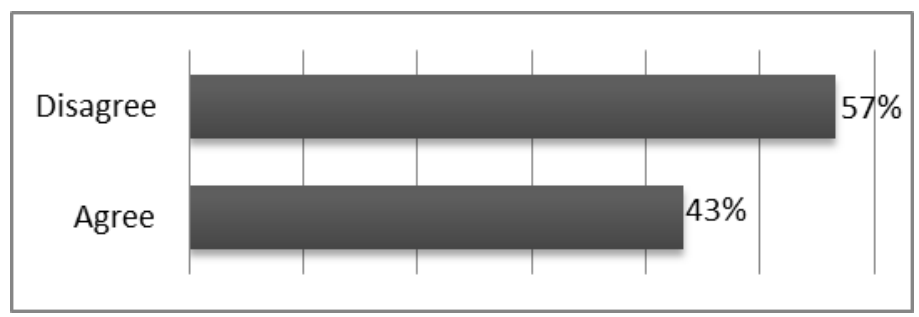

Figure 10: Employer Has The Right To Monitor Employee Mobile Communication Device Usage

Some of these empirical findings tend to augment the work of some researchers, while some of the findings add substance to debate the various issues. Within the Discussion and Conclusion section, we will delve deeper into the results of the survey and their correlation to research discourse. Some of the survey findings are not debatable because they stand on their own evidences.

\section{DISCUSSION AND CONCLUSION}

\section{Work-Life Imbalance Discussion}

Cousins \& Varshney (2009) and Moore \& Pack (2011) suggested that MCDs do not create work-life imbalance and 53\% of the participants surveyed tended to agree. However, $43 \%$ of those non-supervisory employees believe that MCDs do create work-life imbalance, which supports the works of Ceniceros (2011) and also aligns with those individuals surveyed by SHRM (Gurchiek, 2010). These findings tend to imply that there is a close differentiation in views. This variance may suggest that those seeking a more clear understanding of these differences may find their efforts confounded. Although the discourse on increased MCD usage and its effects on work-life imbalance have been constant, there remains no demarcation - legal or otherwise - regarding the everexpanding boundaries of expectations of employers for employees to be accessible and available.

In fact, historically the discourse regarding work hours has permeated society for centuries. Examining the evolution of work-life from the 1700 s through the $21^{\text {st }}$ century, and fully understanding the progression of work-life, may bring us to the conclusion that work-life balance will continue to be a topic of discussion for some time unless there is true realization that it is a complex discussion. 
Examples of the discourse related to work-life were emphasized during the 1700s. A typical work day was 8 t0 10 hours per day because most workers helped raise crops, and their philosophy was that hard work is a necessity. During the 1800 s, the average work week for some Americans was 70 hours and during the $19^{\text {th }}$ century, it is believed that the annual work hours rose by 10 percent. Massachusetts was averaging 74 hour work weeks. Individuals, such as Ira Steward, argued that decreasing the required work hours would raise the standard of living for the workers (Whaples, 2010). Moreover, during these times, clearly delineating work from leisure was difficult and movements spurred to argue for shorter work hours (Whaples, 2010). During the $20^{\text {th }}$ century, there were a series of work hour changes. Moreover, the Federal Public Works Act (1912) set a law that all government contracts must not exceed eight hours and, later, Henry Ford adopted a five-day work week, and yet that was debated as to his motives (Whaples).

The notion of work-life imbalance or balance is something that society has struggled to resolve for centuries, and yet many strive to achieve it; and although the attention of this topic has brought about some change, little has generated work-life balance. Perhaps it is more important to focus on the quality of one's life and the productivity one can generate versus the balance or imbalance of work-life.

\section{Productivity Discussion}

Data from this study helped to answer the initial research question - "Do workers believe MCDs diminish productivity?" The first trend identified in this study was the participants' disagreement with the premise that MCDs diminishes productivity. These participants' responses differ from the findings of Ahmad \& Orton (2010), Mooney \& Lyne (2010), and Petrecca (2010) who contend that MCDs do in fact diminish productivity. Further research is recommended to discover the differences between the perceptions of users and the research.

A second trend observed from the findings depicts, indirectly, how corporations want MCDs to be accessible to their employees. This trend is supported by the majority of participants who reported their companyowned MCDs and the need for these devices to complete their employment duties. The majority of participants reported that their MCDs do indeed enhance employee productivity. These same data points further lead to the conclusion that there is increased significance of MCD usage in the corporate environment. These findings also suggest that companies want to provide the best technology to increase employee productivity, as the current literature advocates, and these empirical findings support the traditional classical management theory.

Further analysis of three other research inquiries regarding productivity factors shows a continued theme whereby participants believe that MCDs are a positive influence on productivity. One question asked if "MCDs were a distraction"; a slight majority of participants favored the perception of the importance of MCDs in the productivity of their work lives. If this trend represents the new working environment, then these participants are in disagreement with Petrecca's (2010) argument on lost productivity due to MCDs.

A third question asked "How many times per day does your MCD interrupt your productivity during work hours?" The participants selected the " 10 or less" interruptions response while eight percent indicated " 21 or more" interruptions. These findings imply that employees perceive they are experiencing few interruptions via their MCD during their work hours. There was no discernment made between work-related MCD interruptions and non-workrelated interruptions. This might indicate that follow-up research is required to determine which interruptions were occurring.

The findings from the study revealed a trend that MCDs are being used in the corporate environment to increase productivity (e.g., $88 \%$ agreed). Conversely, two questions (see Appendix questions 5 and 13) designed to gain additional clarity uncovered ambiguous results. This small variance suggests the need for additional ongoing research to improve the understanding of this phenomenon. This small variance suggests the need for additional ongoing research to improve the understanding of this phenomenon.

The other area of investigation prompted by this research sought to ascertain non-supervisory employees' perceptions regarding the employer's right to monitor various MCD usage in the surveillance of employees' communication activities. Some individuals believe that this form of monitoring is fair and necessary while others 
disagree. Subsequent discussion of employers' rights to monitor company-owned equipment and the rationale of employers to protect their resources is included in the Employer's Right to Monitor Discussion. The rationale of employers' to protect their resources and to provide safe work environments is included in the discussion of findings.

\section{Employer's Right to Monitor Discussion}

The research question, "Do employers have the right to monitor mobile communications device(s)?" revealed $57 \%$ of the participants disagreeing with the right to monitor. The participants' perceptions differed from authors Petrecca (2010), Shilton (2009), and Wicker (2011) who cited the employers' traditional rationale for monitoring employees' phone calls, their (employer's) usage of GPS via Smartphones and other technology devices, and their restriction policy related to the usage of cameras due to company trade secrets interwoven with the standardization of product quality and the provision of a safe workplace environment.

Within the context of this discussion of "employer rights", the significance of worker safety should not be understated. Employers are held legally responsible for employee safety. Rubinstein, Meyer \& Evans (2001) of the Brain, Cognitive and Action Laboratory at the University of Michigan posits that multi-tasking increases the probability for mistakes, which may manifest in an increased risk for possible accidents and injuries in the workplace. Providing protection through monitoring the workplace and the movements of personnel and resources is inextricably bound within the legal responsibilities of the employer.

Eighty-five percent of the participants stated they believed that their employers were not involved in monitoring activity. These participants may be considered naïve, as suggested by the study conducted by Deloitte (2009). These research participants concluded their perception that employers do not have the right to monitor employees' communication activities.

Findings from this research question infer that employees may not have accurate knowledge of whether there is monitoring activity in their workplace. Additional research may reveal that employers have policies and that their employees do not place emphasis on their employers' policies, thus having forgotten that these policies exists. Conversely, some employers may not have clearly articulated policies.

\section{Concluding Remarks}

Glimpses into the importance of MCDs usage in the workplace began with a review of recent literature that identified common themes in this compelling contemporary issue. Subsequently, presented was a detailed description of the research methodology and current study results outlining the participants' responses. The discussion and concluding remarks of the analysis and interpretation of the respondents' perceptions to the three emergent themes - work-life balance, productivity, and employers' right to monitor - revealed the complexity of the importance of MCDs in the participants' lives.

The findings of the current study furthered the discourse by revealing the current perceptions of the importance of MCDs in the professional and personal lives of non-supervisory employees and may be one of the early investigations of an understudied population.

The findings from this study revealed a trend that participants believe MCDs increase work productivity (88\% agreed). However, when asked if MCDs are a distraction, $42 \%$ reported 'yes' while $58 \%$ reported 'no'. This small variance suggests the need for additional on-going research to improve the understanding of this phenomenon.

Empirical analysis would suggest that MCD users are using these devices at a more frequent rate per hour than indicated by the data reported. There is a need for further research study to embed qualifiers which would require future respondents to categorically indentify the types of interruptions generated by MCDs. The analysis of the data collected invites the question whether the respondents enumerated all incoming or self-initiated calls or only those which the respondent experienced as an interruption. Moreover, the importance of the respondent's perception of MCD usage - whether business-owned or otherwise - plays a significant role in how they negotiate their work hours and their personal lives. 
The questions in this research study that are relevant to the amount of interruptions will require further mining in terms of how these interruptions are perceived and how they increase the probability of material loss or employee injuries. Additional inquiries may include the length of interruptions and a distinction made between personal and professional interruptions.

In addition, clarity concerning the word interruptions is necessary because the initial word choice (interruptions) was chosen to keep any biases to a minimum; therefore, more questions to discover if the word elicits positive or negative interpretations for the participants is necessary.

Finally, there are varying views concerning MCDs usage and their relationship to productivity. This research study did reveal the following findings: 1) Despite the productivity increased believed by a majority of the participants, a significant percentage of these participants reported that MCDs created work-life imbalance, 2) A slight majority of participants could not live without their MCDs closely, followed by those who could live without their MCDs, 3) There is a small variance between participants who believe their employer has a right to monitor MCDs usage and those who believe their employer does not have a right to monitor, and 4) This research study's findings revealed that additional research is needed to improve the understanding of these dichotomies.

\section{AUTHORS INFORMATION}

Beverly Carolann Muhammad, D.M., is currently the Director of Curriculum Development for School of Business and Technology Management at Northcentral University. Dr. Muhammad has been with Northcentral University since 2009 in various roles from adjunct faculty to full-time faculty and more recently Director of Curriculum Development. She received her doctorate in 2006 from University of Phoenix and has over 30 years technical and executive experience. She also holds a Master of Science degree in Technology Management and a Bachelor of Science in Management. Phone: (602) 605-8451 E-mail: bcmuhammad@live.com

Conja McMichael-Wright, D.M., is currently the Assistant Manager of the Redford Branch Library, of the Detroit Public Library also a participant in Detroit Future Schools: Artist in Residence program. Conja is a community trainer in Policy Advocacy, University of Michigan Detroit Urban Research Center; member of Community Steering committees with the Kidney Foundation and University of Michigan Public Health researching and planning services and activities in relation to the incidence of diabetes and hyper tension in Northwest Detroit. In addition, she is on the Board of Directors of a youth development organization Strategic Builders Inc. Phone: (313) 273-8149 E-mail: cwmedia@yahoo.com. Education: D.M. University of Phoenix. Wayne State M.I.L.S., B.S. Brooklyn College City of New York

Pamela J. Van Den Bussche, D.M, is currently the principal at Sunrise Valley Associates, Inc. Training and Development Company focusing on organizational leadership with individuals, teams, and leaders facilitating progress by uncovering idle potential, expanding their definition of success, and exploring new perceptions. Pam currently volunteers as a mentoring circle co-leader for the Chicago Chapter of the Healthcare Business Woman Association; member of the Chicago UOP Alumni leadership team, and member of the Local Human Resource Group working with people in transition. Phone: (847) 345-3217 E-mail: pam@ @unrisvalleyassoc.com. Education: D.M. University of Phoenix; M.H.R.M. Keller Graduate School of Management, B.A. Northern Illinois University

Jaime J. Klein, Ph.D., currently works as an online instructor of business at several universities, and she is the owner of Jaime Klein Consulting, a company that assists with statistical analysis of quantitative research. She is currently a member of the National Association of Professional Women. She earned her PhD in Organizational Management from Capella University in 2007, and co-authored several articles since that time. Phone: (352) 3995442 E-mail: jaimeklein@ comcast.net. Education: PhD Capalla University; MBA Franklin University; Bachelors of Science in Business Administration Franklin University. 


\section{REFERENCES}

1. Ahmad, N., \& Orton, P. (2010). Smartphones Make IBM Smarter, But Not As Expected. $T+D, 64(1)$, 4650. http://www.shrm.org/Publications/HRNews/Pages/WorkLifeOffKilter.aspx

2. Ceniceros, R. (2011). Work-life balance healthy for everyone. Business Insurance. Retrieved from: www.lexisnexis.com/hottopics/lnacademic

3. Chesley, N. (2010). Technology Use And Employee Assessments Of Work Effectiveness, Workload, And Pace Of Life. Information, Communication \& Society, 13(4), 485-514. doi:10.1080/13691180903473806

4. Connecticut Department of Labor State of Connecticut Disclaimer and Privacy Policy. 2002-2011State of Connecticut. Retrieved from: www.ctdol.state.ct.us/wgwkstnd/laws-regs/statute31-48d.htm - 11k 2012-03-07

5. Ciocchetti, C. (2010). The Eavesdropping Employer: A Twenty-First Century Framework for Employee Monitoring. Retrieved from: http://www.futureofprivacy.org/wpcontent/uploads/2010/07/The Eavesdropping_Employer_\%20A_Twenty-First_Century_Framework.pdf

6. $\quad$ Cousins, K. C. \& Varshney, U. (2009). Designing Ubiquitous Computing

7. Environments to Support Work Life Balance. Communications Of The ACM, vol. 52, no. 5, pp.117-123.

8. Deloitte's (2009). Ethic \& Workplace Survey Examines he Reputation Risk Implications of Social Network. Deloitte Business Ethic, Research, Reports \& Deloitte May18, 2009. Retrieved from: http://www.mba4success.com/pages/news/news content.php?id=323

9. D'Souza, D. (2010). Mobile Productivity in the Enterprise. Siliconindia, 13(8), 30-31. Retrieved from: http://connection.ebscohost.com/c/articles/61348445/mobile-productivity-enterprise

10. Goodman, C. K. (2011). Balancing Act: Moms back on job; will they stay? Pittsburgh Post- Gazette.com. Retrieved from: http://www.post-gazette.com/stories/business/dateline/balancing-act-moms-back-on-jobwill-they-stay-637785/

11. Greene, T. (2012). Upcoming Microsoft CRM clients may mean more productivity. Network World, 29(3), 12.

12. Gurchiek, K. (2010). Survey: Work/Life Balance Off-Kilter in U.S.. Retrieved from: http://www.shrm.org/Publications/HRNews/Pages/WorkLifeOffKilter.aspx

13. Kalkbrenner, J., \& McCampbell, A. (2011). The Advent Of Smartphones: A Study On The Effect Of Handheld Electronics On Personal And Professional Productivity. Journal Of Applied Global Research, 4(8), 1-9. Retrieved from: http://web.ebscohost.com.proxy1.ncu.edu/ehost/detail?sid=2d62fc73-b248$\underline{4778-8 \mathrm{cdd}-}$ 08485d82e $80 \mathrm{a} \% 40$ sessionmgr113\&vid=1\&hid=106\&bdata=JnNpdGU9ZWhvc3QtbGl2ZQ\%3d\%3d\#db=0 $\underline{\text { fs\&AN }=66210970}$

14. Mooney, P., \& Lyne, M. (2010). Do Smartphones reduce productivity? Director, 64(4), 34-34. Retrieved from: http://search.proquest.com/docview/821278256?accountid=28180

15. Moore, B. and Pack, A. (2011). Workplace Surveillance: Balancing the Employee's Rights to Privacy with the Employer's Right to Know. West Virginia Chamber HR Journal. Retrieved from http://www.dinsmore.com/workplacesurvelliance

16. Nelson, R. (2012). Mobile Apps Support Communications Test, Data Acquisition. EE: Evaluation Engineering, 51(1), 20-24. Retrieved from: http://www.evaluationengineering.com/articles/201201/mobile-apps-support-communications-test-dataacquisition.php

17. Petrecca, L. (2010). “Feel like someone's watching? You're right”. USA Today March 16, 2010. Retrieved from: http://www.usatoday.com/MONEY/usaedition/2010-03-17workplaceprivacy 15 CV U.htm December 2011

18. PEW (2006). PEW Internet \& American Life Project. PEW Internet Project Data Memo. Associated Press. Retrieved from: http://www.pewinternet.org/ /media/Files/Reports/2006/PIP_Cell_phone_study.pdf.pdf December 2011

19. Rubinstein, J. S., Meyer, D. E., \& Evans, J. E. (2001). Executive Control of Cognitive Processes in Task Switching. Journal of Experimental Psychology: Human Perception and Performance, 27(4),763-797. doi: 10.1037/0096-1523.27.4.763 
20. Shilton, k., Burke, J.A., Estrin, D., Govindan, R., Hansen, M., Kang, J. \& Mun, M. (2009). Designing the Personal Data Stream: Enabling Participatory Privacy in Mobile Personal Sensing. Ethics in Science and Engineering National Clearinghouse. Retrieved from: http://www.ethicslibrary.org/resources/444

21. Smith, A. (2010). Americans and their gadgets. Pew Research Center's Internet \& American Life Project. Retrieved from: http://www.pewinternet.org/ /media/Files/Reports/2010/PIPAmericans\%20and\%20their\%20Gadgets.pdf

22. Supreme Court of United States (2009). City of Ontario,m California, et al., Petitioners v Jeff Ouaon,et. al. Retrieved from: http://www.supremecourt.gov/opinions/09pdf/08-1332.pdf

23. Whaples, Robert (2001). "Hours of Work in U.S. History" EH.Net Encyclopedia. Edited by Robert Whaples. Retrieved from: http://eh.net/encyclopedia/article/whaples.work.hours.us

24. Wicker, S.B. (2011). A Little Too Smart The Loss of Location Privacy in the Celluar Age. Retrieved from: http://www.science.smith.edu/ jcardell/Courses/EGR390/Readings/ACM_LocationPrivacy.pdf 


\section{APPENDIX A}

1. Do your employment duties require use of mobile communication devices to conduct business?

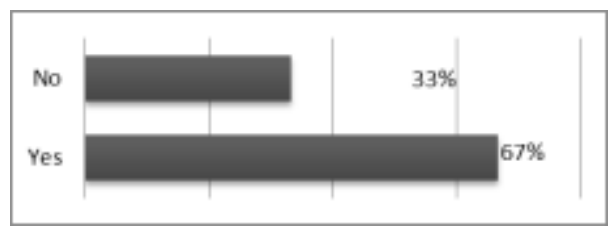

2. Select the Mobile Communication Devices you use for business purposes.

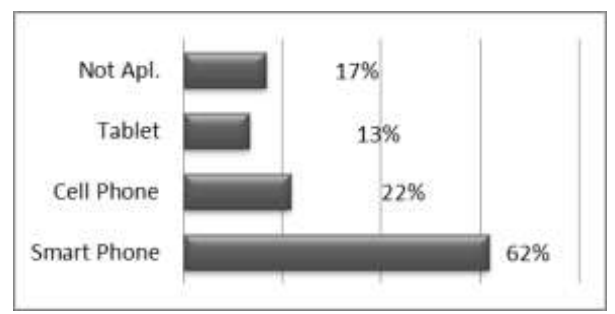

3. Select the Mobile Communication Device(s) you use for personal purposes.

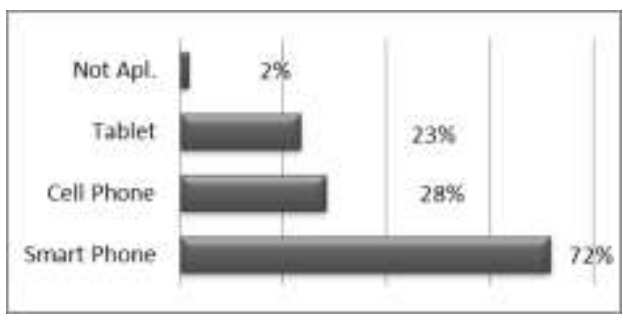

4. Select the company owned Mobile Communication Device(s).

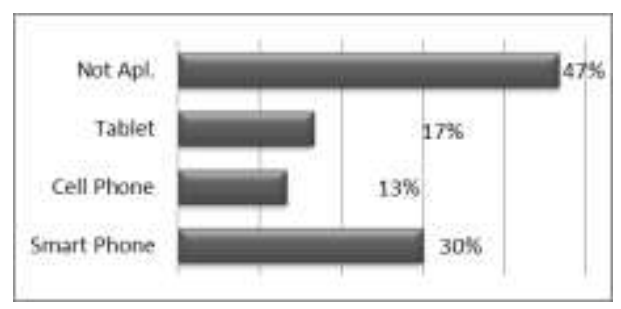

5. How many times per day does your mobile communication device interrupt your productivity during work hours?

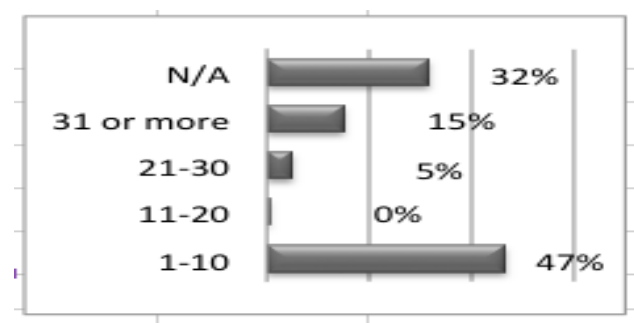


6. When does your employer require you to answer your Mobile Communication Device?

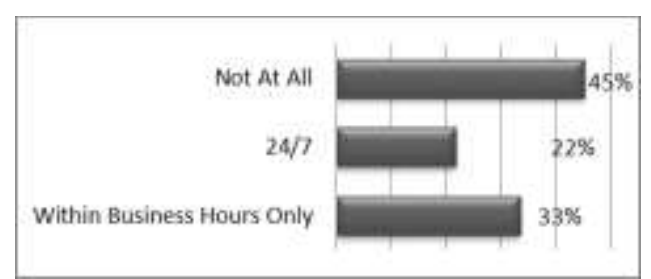

7. Mobile Communication Devices have created an imbalance between work and personal life.

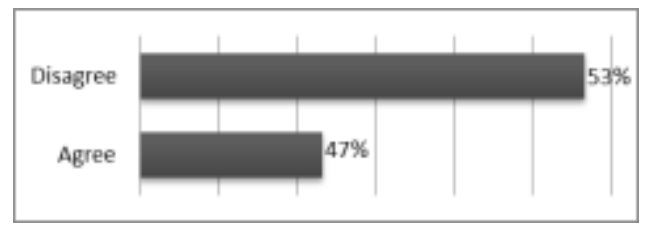

8. Using Mobile Communication Devices have increased my productivity.

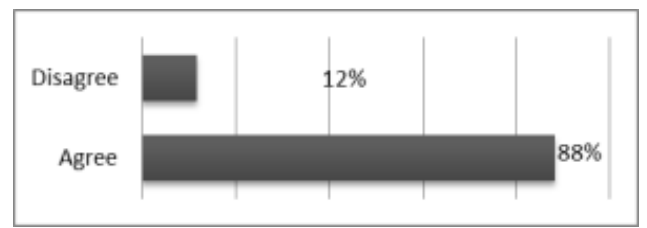

9. My employer has the right to monitor employee mobile communication device usage.

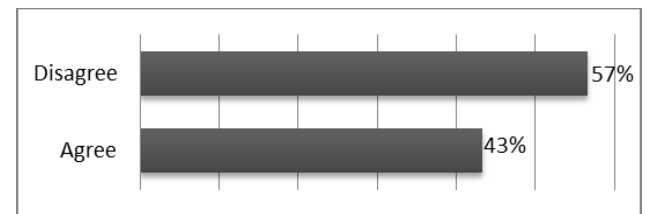

10. I cannot live without my Mobile Communication Devices.

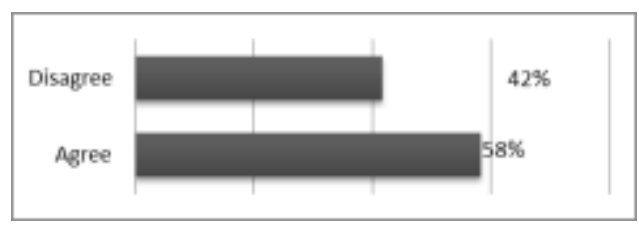

11. Does your employer monitor your Mobile Communication Devices?

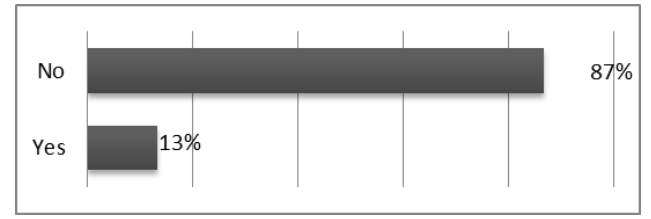


12. Are you compensated for answering your mobile before or after work hours?

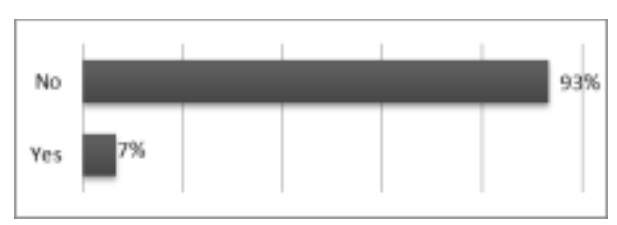

13. Mobile Communication Devices are a distraction.

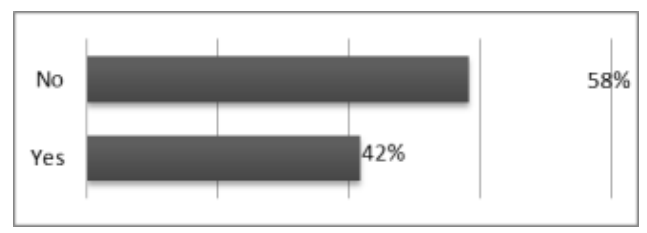

14. Does your employer have a policy requiring you to turn off your cell phone?

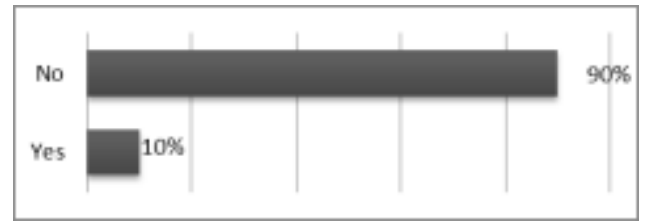

15. Select the personally owned Mobile Communication Devices reimbursed by your company.

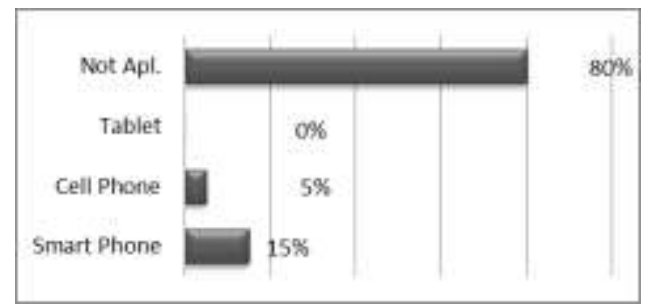

